\title{
Influence of Late Season Harvesting, Fall Grazing, and Fungicide Treatment on Verticillium Wilt Incidence, Plant Density, and Forage Yield of Alfalfa
}

\author{
F. A. Gray and D. W. Koch, Professors, Department of Plant Sciences, POB 3354, University of Wyoming, Laramie \\ 82071-3354
}

\begin{abstract}
Gray, F. A., and Koch, D. W. 2004. Influence of late season harvesting, fall grazing, and fungicide treatment on Verticillium wilt incidence, plant density, and forage yield of alfalfa. Plant Dis. 88:811-816.

Studies were conducted in the presence of Verticillium wilt (Verticillium albo-atrum) to determine the effect of fall harvesting and grazing over time on plant stand and forage yield of alfalfa (Medicago sativa). Resistant and susceptible cultivars were tested on established and newly seeded fields. In the fall (experiments 1 and 2), cultivars were either: (i) cut (third time); (ii) grazed; (iii) cut and grazed; or (iv) left uncut and ungrazed. Although Verticillium was present, test sites for experiments 2 and 3 were sprayed with a spore suspension of $V$. albo-atrum immediately following the first cutting of each experiment to standardize disease pressure. In experiment 1, the moderately resistant cultivar Apollo II, harvested twice without a late third cutting or fall grazing, produced the highest forage yield the following year. Fall grazing reduced subsequent yields in both the 2- and 3-cut treatments. In experiment 2, a third cutting decreased plant density and forage yield in both resistant and susceptible cultivars, while grazing had no effect. Neither fall treatment affected incidence of Verticillium wilt. In experiment 3, application of the fungicide benomyl to plant stubble following each harvest decreased Verticillium wilt in Apollo but not in Arrow. Overall, with the resistant cultivar Arrow, harvesting twice annually and grazing after a killing frost in lieu of late fall cutting slowed disease development, prolonged stand life, and maximized forage yield and quality.
\end{abstract}

Additional keywords: crown rot, disease management, host resistance, lucerne

Verticillium wilt (caused by Verticillium albo-atrum Reinke \& Berthier) of alfalfa (Medicago sativa L.) was first found in the United States in Washington in 1976 (4). V. albo-atrum was most likely introduced into the United States by diseased seed $(1,2)$. Once established in commercial seed fields in the Pacific Northwest, it is believed to have spread via seed to other alfalfa growing regions in the United States (3). Verticillium wilt (VW) was first found in Wyoming in 1981 (6), and it is now present in all major alfalfa growing areas in the state (14). The major means of secondary spread of V. albo-atrum within and between fields occurs with infected plant material carried on the cutter bar of commercial swathers $(7,11)$. Plant infection by $V$. albo-atrum occurs via freshly cut stems following mowing (16), while the inoculation of injured leaves was shown not to result in plant infection (9). In a greenhouse test, inoculation of freshly cut stems of 9-weekold VW-susceptible alfalfa (Vernal) with a spore suspension of a Wyoming isolate of

Corresponding author: F. A. Gray

E-mail: fagray@uwyo.edu

Accepted for publication 16 March 2004.

Publication no. D-2004-0524-01R

(C) 2004 The American Phytopathological Society
V. albo-atrum resulted in $90 \%$ incidence of VW after 4 weeks (6). In the Pacific Northwest, symptoms first appeared on plants in 2-year-old fields (3), and plant stands declined as early as the third year (15). High rainfall, high relative humidity, and optimum temperatures $\left(20\right.$ to $\left.25^{\circ} \mathrm{C}\right)$ in the spring and fall are conducive for $V$. albo-atrum infection and disease development. Symptoms occur less frequently when temperatures are above $32^{\circ} \mathrm{C}$ and conditions are dry. Hot and dry conditions, however, cause additional water stress in diseased plants and may result in their collapse and/or death (13). In the Pacific Northwest, VW has only been reported in alfalfa fields that receive supplemental irrigation and appears to be more severe under sprinkler irrigation $(1,11)$.

Wyoming (5) and New York (20) studies showed significant benefit from the use of resistant cultivars in the presence of VW. Foliar symptoms of VW first appeared in Wyoming at the end of the second production year. Statistical separation of susceptible and resistant cultivars, relative to forage yield, was measured during the third production year. Although stands in all cultivars declined, rate of stand decline decreased with an increasing level of host resistance. Disease and plant densities both were negatively correlated with yield during the third production year. Economic impact of VW in irrigated alfalfa in Wyo- ming was estimated in 1988 to be $\$ 1.73$ million annually (14).

In cattle operations in Wyoming and other Rocky Mountain states, late season alfalfa regrowth is commonly cut prior to temperatures below $-4^{\circ} \mathrm{C}$, or it is grazed after a killing frost. Also, since late season cuttings of hay are often difficult to cure in the fall, regrowth is preferably grazed after a killing frost, which also minimizes bloat of cattle. Observations on the Padlock Ranch in northern Wyoming indicated that late season haying followed by fall grazing in the presence of VW may have been responsible for early stand decline and reduced forage yield in the moderately resistant alfalfa cultivar Apollo II.

Studies were conducted to: (i) determine the influence of late season harvesting (late third cutting) and/or fall grazing of regrowth, after a killing frost, on incidence of VW, plant density, and forage yield in both resistant and susceptible alfalfa cultivars, and (ii) assess the degree of VW control provided by a VW-resistant cultivar with a fungicide treatment.

\section{MATERIALS AND METHODS}

Three experiments were conducted over a 9-year period (1986 to 1994). In the first experiment, a VW-moderately resistant cultivar was used, while in the second and third experiments, both resistant and susceptible cultivars were used. Once treatments were established, they were maintained in the same plots for the duration of each of the three experiments. All experiments were located in sprinklerirrigated fields on the Padlock Ranch near Dayton, WY. Certified alfalfa cultivars were used in all experiments. Fall dormancy and disease ratings of cultivars are presented in Table 1.

The Padlock Ranch is located on the eastern slope of the Big Horn Mountains in northern Wyoming at an elevation of 1,219 $\mathrm{m}$ with 95 frost-free (above $-4^{\circ} \mathrm{C}$ ) days and an average annual precipitation (rain and snow) of $30.5 \mathrm{~cm}$. Depending on fall weather conditions (early killing frost or snow cover), fields are cut two or three times. Alfalfa regrowth following the second cut is usually grazed after a killing frost, thus preventing bloat of beef cattle.

Experiment 1. This experiment was designed to evaluate the effect of late season harvesting and grazing, in the presence of VW, on 2-cut yields the following year and on final plant density. The experiment was 
designed to determine if our earlier observation-that late season haying and/or grazing in the presence of VW resulted in the decline of plant stand in Apollo IIwas valid. The experiment was initiated in the fall of 1986 and was superimposed on an existing 3-year-old field of Apollo II alfalfa, moderately resistant to VW (Table 1). The field had been seeded at $16.8 \mathrm{~kg}$ $\mathrm{ha}^{-1}$ on $16.5-\mathrm{cm}$ row spacing in the spring of 1983. The soil at the site was a Nuncho clay loam (fine montmorillonitic, mesic, Acridic Argiustoll) with pH 6.3. Soil phosphorus (P) was high (>22 ppm), as determined by the sodium bicarbonate method (12), as was soil potassium (K) (>100 ppm) (19). The field had been harvested once in 1983. Each year after forage had dried following a killing frost, beef cattle grazed the test site until forage was removed. Symptoms of VW had been present in the test site since the spring of 1985.

The experiment consisted of four treatments: 1,2 cuts (designated as the check); 2, 2 cuts followed by fall grazing after a killing frost (the standard harvest method on the ranch); 3,3 cuts without fall grazing; and 4, 3 cuts followed by fall grazing. Treatments 3 and 4 were harvest methods occasionally practiced on the ranch in years having an extended fall or when winter feed was needed. Treatments were selected to determine if late season cutting and/or fall grazing were responsible for an increase in VW, accelerated decline of plant density, and reduced yield. Treatments were imposed on the same plots during 1986 and 1987, and the residual effect on 2-cut forage yields was measured in 1987 and 1988. When the test was established in 1986, the field had been previously cut on 17 June (first cut) and on 25 July (second cut). Treatments were arranged in a randomized complete block design with four replications (16 plots). Forage yield of plots $(3.7 \times 3.7 \mathrm{~m})$ was obtained with a commercial swather. Subsamples from each plot were taken from harvested forage, dried, percent moisture determined, and plot weights adjusted to $12 \%$ moisture.

Prior to the third cutting on 2 September 1986 , overall incidence of VW in the test site was estimated at $20 \%$ of plants re- maining. Additional disease ratings were not taken in 1987 or 1988 . There were 1.8$\mathrm{m}$ alleys between plots and replicates to facilitate placement of fenced exclosures for nongrazed plots. The field was irrigated biweekly. A third cutting (treatments 3 and 4) was taken on 2 September, and grazing (treatments 2 and 4) started on 23 October. Several days after the regrowth of alfalfa had frosted and the soil surface was sufficiently dry, beef cattle, at a stocking rate of 5 cows per ha, were allowed to graze plots. When forage was consumed in all grazed plots (5 to 7 days), cattle and exclosure panels were removed.

In 1987, plots were cut on 9 June, 20 July, and 6 October, and fall grazing on the same plots as in 1986 was initiated on 28 October. During the early spring of both harvest years, remaining dead alfalfa aftermath was mowed off the nongrazed plots prior to green-up. This was primarily needed in the 2-cut, nongrazed plots. Following the first harvest on 9 June 1988, the alfalfa field surrounding the test site was plowed out by the farm manager due to the declining stand and planted to oats. Prior to the establishment of the oat crop, invasion of the plots by the Northern pocket gopher (Thomomys talpoides Richardson) from the surrounding field soon devastated the entire test site. Therefore, plots were not harvested a second time in 1988, as the test was abandoned.

At the beginning of the experiment in the fall of 1986, plant density (percent plants remaining) averaged over the entire test site was visually estimated at $60 \%$ of a perfect stand. Plots were visually assessed on 25 May 1988 to determine treatment effect on plant density. No other standdecline diseases were identified at the test site.

Experiment 2. This experiment was designed to evaluate the effect of late season cutting and fall grazing on 2-cut forage yield the following year. The experiment was seeded on 1 June 1989 at a rate of $13.5 \mathrm{~kg}$ pure live seed per ha on $16.5-\mathrm{cm}$ row spacing. The soil was a Nuncho clay loam with $1.8 \%$ organic matter, $41 \%$ sand, $24 \%$ silt, $35 \%$ clay, and $\mathrm{pH}$ 7.3. Potassium and phosphorus fertilizers were applied prior to seeding as per University of Wyoming soil test recommendation. The pre-

Table 1. Certified alfalfa cultivars used in the three experiments

\begin{tabular}{lllcccc}
\hline \multirow{2}{*}{$\begin{array}{l}\text { Experiment no./ } \\
\text { test year }\end{array}$} & Cultivar & Marketer & $\begin{array}{c}\text { Fall dormancy } \\
\text { ratinga }\end{array}$ & \multicolumn{2}{c}{ Level of disease resistance $^{\mathbf{b}}$} \\
\hline $1 / 1986-88$ & Apollo II & AgriPro & 4 & VW & ASN & PRR \\
\hline $2 \& 3 / 1989-94$ & Arrow & ABT/Agri Pro & 3 & MR & MR & HR \\
& Apollo & AgriPro & 4 & R & MR & HR \\
& & & & S & MR & R \\
\hline
\end{tabular}

${ }^{\text {a }}$ Fall dormancy is rated on a scale of 1 to 11 , with 1 being the most dormant.

${ }^{\mathrm{b}}$ Disease abbreviations are: VW $=$ Verticillium wilt, $\mathrm{PRR}=$ Phytophthora root rot, $\mathrm{ASN}=$ alfalfa stem nematode. Disease ratings are: $\mathrm{HR}=$ highly resistant, $\mathrm{R}=$ resistant, $\mathrm{MR}=$ moderately resistant, $\mathrm{LR}$ $=$ low resistance, $\mathrm{S}=$ susceptible. Levels of disease resistance are defined as: $\mathrm{S}=0$ to $5 \%$ of plants resistant, $\mathrm{LR}=6$ to $14 \%, \mathrm{MR}=15$ to $30 \%, \mathrm{R}=31$ to $50 \%$, and $\mathrm{HR}=>50 \%$. These disease categories are only used for cultivars approved by the National Alfalfa Certification Review Board. emergence herbicide Eptam 7 EC (EPTC) was preplant incorporated at $3.0 \mathrm{~kg}$ a.i./ha to reduce weed competition. No further application of herbicides was made during the remainder of the test period. Plots were sprinkler-irrigated daily until establishment, and then biweekly thereafter following each harvest. The field had a history of alfalfa for 15 to 20 years separated every 5 to 6 years with 1 year of a small grain crop when alfalfa stands became severely depleted. Barley was grown for silage in 1988. After plots were established, the remainder of the 32-ha field was planted with the resistant alfalfa cultivar WL 316.

In addition to the cutting and grazing treatments used in experiment 1 , two cultivars were evaluated. Both cultivars had been grown on the ranch, but differed in their reaction to VW. Arrow was resistant and Apollo was susceptible to VW, and both had similar resistance to Phytophthora root rot (P. megasperma Drechs. f. sp. medicaginis T. Kuan \& D.C. Erwin) and the alfalfa stem nematode, Ditylenchus dipsaci Kühn (Filipjev) (Table 1), which had been identified on the ranch. Treatments were imposed on the same plots for 4 years (1990 through 1993). Procedures for cutting and grazing were the same as those described for experiment 1.

The experiment was conducted as a split plot in space and time. Years were factor A and cultivars were factor B. Two cutting and two grazing treatments, the same as in experiment 1, were assigned (randomized complete block) within cultivars. All treatments were replicated three times. Plots were $3.7 \times 4.6 \mathrm{~m}$ and were designed for cutting with a $3.7-\mathrm{m}$-wide commercial swather. There were $1.8-\mathrm{m}$-wide alleys between replications and plots to facilitate fenced exclosures of nongrazed plots.

Data collected included plant density in the spring (1989 through 1994), incidence of VW prior to the first harvest (1991 through 1994), and forage yield (1990 through 1994). During the year of seeding and the following years (1989 and 1990), before VW was established, plots were cut once and twice, respectively. Forage yield was not determined in 1989 but was recorded in 1990. Forage yields of all four treatments were taken beginning in 1991 (year 3) through 1994 (year 6). Freshly harvested forage from each plot was weighed and subsamples collected for moisture determination and plot weight converted to $12 \%$ moisture. In all harvest years, the first cut was made in mid-June, the second cut in mid-August, and the third cut (3-cut treatments) in late September to early October. Grazing of alfalfa killed by frost occurred between mid-October and early November. To determine botanical composition of forage, $0.5 \mathrm{~m}^{2}$ quadrant samples were taken from each plot just prior to the first cut in the spring of 1993 (year 5) and 1994 (year 6). Forage was separated into alfalfa and weeds (grass and 
broadleaf), dried, and weighed. Plant density (percent remaining plants) was visually determined by the same person each spring.

VW was first detected in plots in the fall of 1990. Beginning in 1991, plots were rated for disease incidence (percent remaining plants with VW symptoms) by the same person each spring prior to the first harvest. Although VW was usually evident in the spring and fall when temperatures were cool, the most favorable time for disease ratings was during the spring following rain showers, which encourage disease expression. However, to ensure uniform infection, all plots were sprayed with a suspension of $V$. albo-atrum spores (isolate from the Padlock Ranch) immediately following the first harvest on 27 June 1992 (year 4). A V. albo-atrum spore suspension $\left(150 \mathrm{ml}\right.$ at $5.1 \times 10^{7}$ conidia per ml) was applied to each plot using a $\mathrm{CO}_{2}$ pressurized backpack sprayer as previously described (5).

Following the second harvest on 15 October 1994 (year 6), when the experiment was terminated, 10 plants were selected arbitrarily and dug from each of the 24 plots and observed for symptoms of crown rot. Tissue isolations were not attempted.

Observations made following grazing and after cattle and exclosure panels were removed indicated forage on all grazed plots had been removed evenly.

Experiment 3. The purpose of this experiment was to determine if disease control was maximized in the VW-resistant cultivar Arrow by comparing fungicide and no fungicide treatments. Soil type, fertilizer application, seeding rate, irrigation, and herbicide application were the same as for experiment 2. The experiment was conducted as a split plot in space and time. Years were factor $\mathrm{A}$ and cultivars were factor B. Fungicide and no fungicide plots were randomly assigned in a randomized complete block within cultivars. All treatments were replicated six times. Main plots (cultivars) were $3.7 \times 4.6 \mathrm{~m}$ in size. Each plot was split lengthwise $(1.8 \times 4.6$ m) for subplots, which were either sprayed immediately after harvest with the systemic fungicide benomyl (Benlate 50WP) or left unsprayed. During the year of seeding (1 June 1989) and the following year (1990), plots were cut once and twice, respectively, but forage yield was not taken. Frosted regrowth on the entire test site was grazed each year beginning in the fall of 1989 as described in experiment 2. VW was first detected in plots in 1990. From 1991 through 1994, all subplots were harvested twice yearly at the $10 \%$ bloom stage. A 0.8 -m-wide swath was harvested (TROY-BILT sickle bar mower) from the center of each subplot and fresh weight determined. Subsamples were collected from each plot for moisture determination and plot weight converted to $12 \%$ moisture. Immediately after plots were cut, the remaining alfalfa in the test site was harremoved. To ensure uniformity of VW, all plots were sprayed with $V$. albo-atrum spores as described in experiment 2. Composition of forage was determined in the first cut in 1993 and 1994, as described for experiment 2 .

Immediately after each harvest, plots were either left unsprayed or stubblesprayed with benomyl. The $\mathrm{CO}_{2}$ backpack sprayer (Weed Systems Equipment, Inc., Keystone Heights, FL) delivered 75 liters/ha containing benomyl at $10.3 \mathrm{~kg}$ a.i. $\mathrm{ha}^{-1}$. The first spray was applied following the single cut in 1989, and the last spray was applied following the second cut in 1993 (nine total sprays).

Disease incidence was determined from the spring of 1991 through the spring of 1994 , and plant density was visually determined each spring from 1989 through 1994. Disease incidence and plant density were determined by the same person each year.

Statistical analysis. Data were subjected to the SAS general linear models vested with a commercial swather and

(GLM) procedure. Means of treatments for the variables were compared using Fisher's protected least significant difference test at $P=0.05$.

\section{RESULTS}

Experiment 1. Two-cut forage yield of the VW-resistant cultivar Apollo II was reduced by an additional third (fall) cutting the previous year $(P=0.05)$ in 1987 , but not in $1988(P=0.21)$ (Table 2$)$. Yields were also reduced by fall grazing in both the 2- and 3-cut treatments in $1987(P=$ $0.03)$ and $1988(P=0.02)$. The 2 -cut treatment produced the greatest total (1987-88) forage yield (13.56 $\mathrm{Mg} \mathrm{ha}^{-1}$ ). Compared with the check (2-cut) treatment, taking a third harvest in the fall decreased forage yield by $6.3 \%$ over the 2 years (1987-88), while grazing fall growth decreased yield $9.0 \%$. Plant density at the end of the study on 25 May 1988, although higher with 2 cuts, did not differ $(P=0.42)$ among harvest treatments (Table 2).

Experiment 2. First detection of VW $(<1.0 \%$ plants with VW) occurred in both cultivars in the fall of year 2 (Fig. 1). Dis-

Table 2. Influence of Verticillium wilt (VW), late season harvesting, and fall grazing on 2-cut forage yield the following year and on final plant density in established, VW-moderately resistant Apollo II alfalfa, experiment $1^{\text {a }}$

\begin{tabular}{|c|c|c|c|}
\hline \multirow{2}{*}{$\begin{array}{l}\text { Harvesting } \\
\text { method }(1986-1987)^{b}\end{array}$} & \multicolumn{2}{|c|}{$\begin{array}{c}\text { Two-cut forage yields } \\
\left(\mathrm{Mg} \mathrm{ha}^{-1} \text { at } 12 \% \text { moisture }\right)\end{array}$} & \multirow{2}{*}{$\begin{array}{c}\begin{array}{c}\text { Final plant density } \\
(\% \text { plants remaining) }\end{array} \\
\mathbf{5 / 2 5 / 8 8}(\text { year } 5) \\
\end{array}$} \\
\hline & 1987 (year 4) & $1988($ year 5) & \\
\hline 2 cuts (check) & 10.60 & 2.96 & 57.5 \\
\hline 2 cuts + fall grazing & 9.79 & 2.55 & 47.5 \\
\hline 3 cuts & 9.92 & 2.78 & 43.8 \\
\hline 3 cuts + fall grazing & 9.32 & 2.31 & 46.3 \\
\hline LSD $P=0.05$ & 0.58 & 0.24 & $\mathrm{~ns}$ \\
\hline
\end{tabular}

${ }^{a}$ Values are average of four replicates.

${ }^{\mathrm{b}}$ The field was seeded to Apollo II in the spring of 1983. Treatments were imposed during 1986 and 1987, and their effect on 2-cut forage yield was determined in 1987 and 1988. Final plant densities were determined in the spring of year 5 (1988). Due to gopher invasion, only one cutting was made in 1988 .

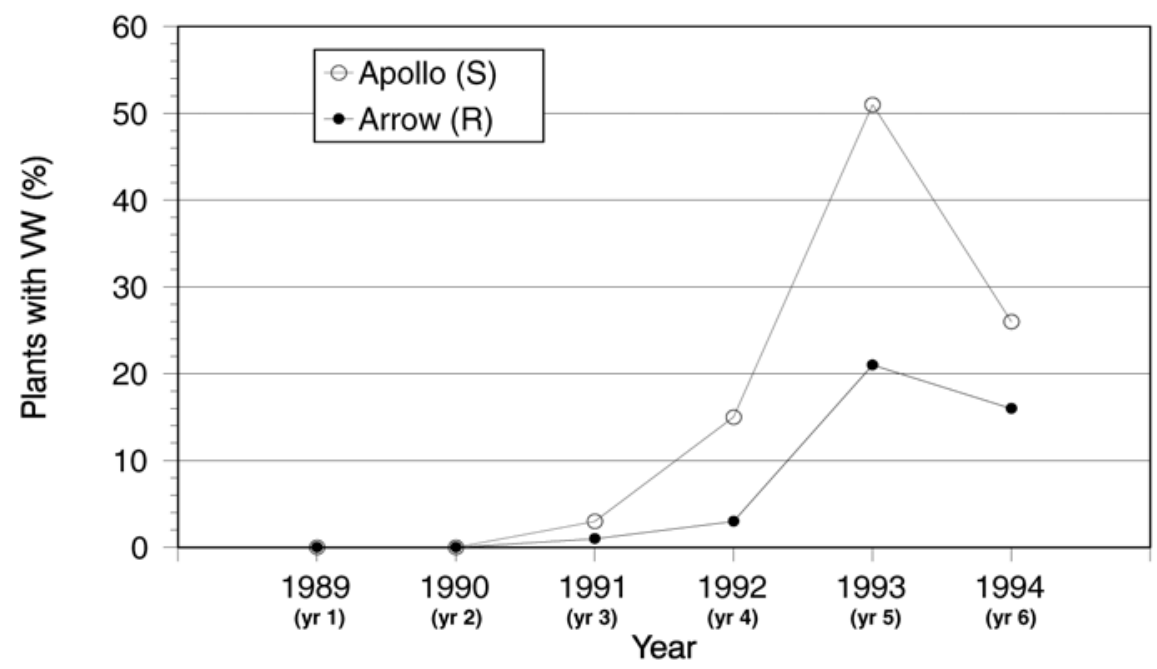

Fig. 1. Disease progress curves for percent plants symptomatic for Verticillium wilt (VW) in susceptible (S) alfalfa cultivar Apollo and resistant (R) alfalfa cultivar Arrow. Data are averaged over cutting and grazing methods and are the mean of three replicates. Cultivar $\times$ year interaction $(P<0.0001)$. Interaction LSD $0.05=22.3$. Experiment 2 . 
Table 3. Analysis of variance for experiments 2 and 3, showing effects of cultivars, number of cuttings, grazing, and fungicide on forage yield, incidence of Verticillium wilt (VW), and alfalfa stand characteristics

\begin{tabular}{|c|c|c|c|c|c|c|c|c|c|}
\hline & \multirow[b]{2}{*}{ df } & \multicolumn{2}{|c|}{ Forage yield } & \multicolumn{2}{|c|}{ Verticillium incidence } & \multicolumn{2}{|c|}{ Plant density } & \multicolumn{2}{|c|}{ Alfalfa content of forage } \\
\hline & & $\boldsymbol{F}$ & $P>F$ & $\boldsymbol{F}$ & $P>F$ & $\boldsymbol{F}$ & $P>F$ & $\boldsymbol{F}$ & $P>F$ \\
\hline & & \multicolumn{8}{|c|}{ Experiment 2} \\
\hline Cultivar (CV) & 1 & 26.01 & $<0.0001 * * * \mathrm{a}$ & 80.05 & $<0.0001 * * *$ & 97.57 & $<0.0001 * * *$ & 16.84 & $0.0004 * * *$ \\
\hline Cutting (CT) & 1 & 7.82 & $0.007 * *$ & 1.04 & 0.31 & 22.43 & $<0.0001 * * *$ & 0.02 & 0.89 \\
\hline $\mathrm{CV} \times \mathrm{CT}$ & 1 & 3.38 & 0.07 & 0.42 & 0.52 & 0.76 & 0.39 & 2.13 & 0.16 \\
\hline Graze $(G)$ & 1 & 0.05 & 0.83 & 0 & 0.97 & 0.36 & 0.55 & 0.04 & 0.84 \\
\hline $\mathrm{CV} \times \mathrm{G}$ & 1 & 3.35 & 0.07 & 0.05 & 0.83 & 0 & 0.98 & 0.52 & 0.48 \\
\hline $\mathrm{CT} \times \mathrm{G}$ & 1 & 0.09 & 0.77 & 0.02 & 0.88 & 0.01 & 0.92 & 2.92 & 2.92 \\
\hline $\mathrm{CV} \times \operatorname{Year}(\mathrm{Y})$ & 3 & 4.77 & $0.0005 * * *$ & 18.54 & $<0.0001 * * *$ & 9.45 & $0.005 * *$ & 0.55 & 0.47 \\
\hline $\mathrm{CT} \times \mathrm{Y}$ & 3 & 0.42 & 0.74 & 2.06 & 0.12 & 12.79 & $0.001 * * *$ & 0.21 & 0.65 \\
\hline \multirow[t]{2}{*}{$\mathrm{G} \times \mathrm{Y}$} & 3 & 0.35 & 0.79 & 0.08 & 0.97 & 0.13 & 0.71 & 0.4 & 0.53 \\
\hline & & \multicolumn{8}{|c|}{ Experiment 3} \\
\hline Cultivar (CV) & 1 & 22.12 & $<0.0001 * * *$ & 42.95 & $<0.0001 * * *$ & 117.55 & $<0.0001 * * *$ & 3.82 & $0.02 *$ \\
\hline Fungicide (F) & 1 & 3.53 & 0.07 & 4.32 & $0.04 *$ & 2.64 & 0.12 & 4.6 & $0.04 *$ \\
\hline $\mathrm{CV} \times \mathrm{F}$ & 1 & 0.29 & 0.59 & 0.61 & 0.44 & 0.22 & 0.64 & 1.07 & 0.31 \\
\hline $\mathrm{CV} \times \operatorname{Year}(\mathrm{Y})$ & 3 & 0.52 & 0.67 & 1.2 & 0.28 & 2.25 & 0.15 & 0.01 & 0.93 \\
\hline $\mathrm{F} \times \mathrm{Y}$ & 3 & 2.66 & 0.06 & 2.34 & 0.14 & 0.05 & 0.83 & 0.69 & 0.41 \\
\hline
\end{tabular}

a $*, * *, * * *=$ significant at $P<0.05,0.01$, and 0.001 , respectively. There were no significant three-way interactions.

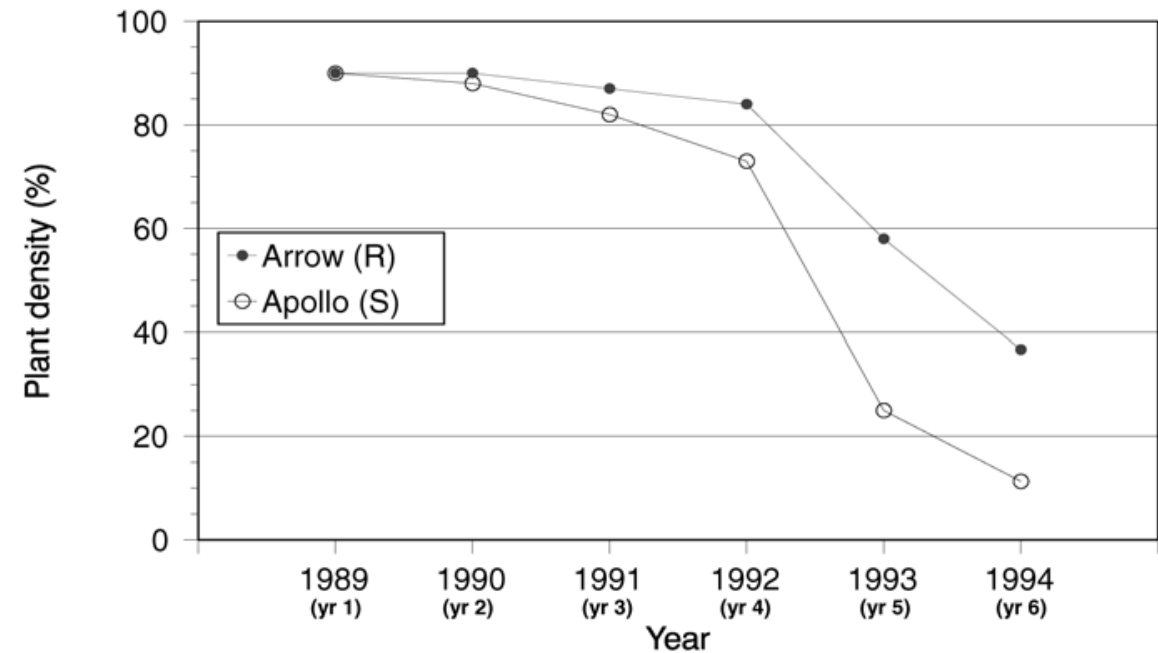

Fig. 2. Change in plant density over time for the Verticillium wilt (VW)-susceptible (S) alfalfa cultivar Apollo and VW-resistant (R) cultivar Arrow grown in the presence of VW. Data are averaged over cutting and grazing methods. Cultivar $\times$ year interaction $(P=0.005)$. Interaction LSD 0.05 $=10.5$. Experiment 2.

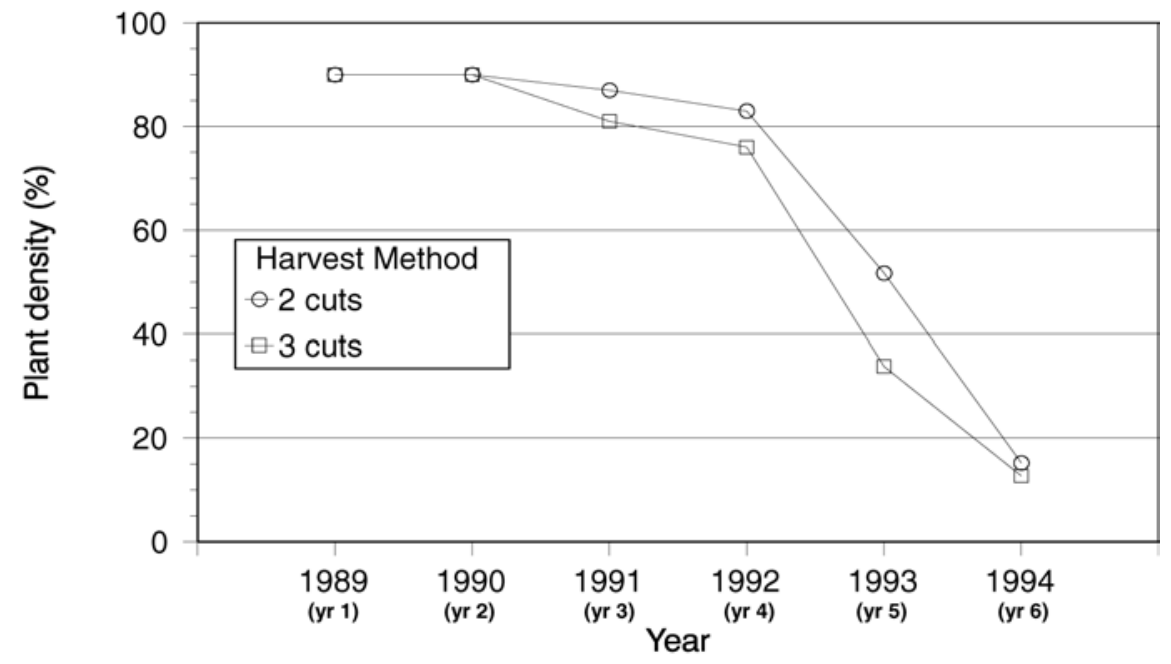

Fig. 3. Effect of two versus three cuttings of alfalfa on plant density over time. Data are averaged over alfalfa cultivars and grazing methods. Cutting methods were imposed from year 2 through year 5 . Cutting method $\times$ year interaction $(P=0.001)$. Interaction LSD $0.05=5.6$. Experiment 2. ease ratings were initiated in the spring of year 3 . There was a cultivar $\times$ year interaction for incidence of VW (Table 3). Incidence of VW increased at a greater rate in susceptible Apollo than in resistant Arrow until year 5. In year 5, Apollo had $51 \%$ of remaining plants and Arrow had $21 \%$ of remaining plants symptomatic for VW. Due to mortality of diseased plants, which severely reduced plant density, VW incidence declined in year 6 in both cultivars. Neither number of cuttings nor fall grazing affected incidence of VW (Table 3).

There was a cultivar $\times$ year and a cutting $\times$ year interaction with respect to alfalfa stand density (Table 3). Reduction of plant density in Apollo was first noticed in year 2 and in Arrow in year 3 (Fig. 2). Stand declined more rapidly in Apollo than in Arrow, with the greatest difference occurring in years 5 and 6 . When the experiment was terminated, plant densities for Arrow and Apollo were 36.7 and $11.3 \%$, respectively. Fall cutting, but not fall grazing, reduced alfalfa plant density (Table 3 ). Plots cut twice maintained better alfalfa stands than those cut three times from year 3 through year 6 , although plant density in both cutting treatments declined rapidly after year $4(P=0.005$, Fig. 3$)$. The greatest difference in plant density between 2cut and 3-cut treatments occurred in year 5, 51.7 versus $33.8 \%$.

Prior to initiating fall cutting and grazing treatments, the 2-cut forage yields of Apollo and Arrow for year 2 were 10.81 and $12.15 \mathrm{Mg} \mathrm{ha}^{-1}$, respectively $(P=0.13)$ (data not shown). There was a greater decline in forage yield of Apollo than Arrow after the peak yield in year 4 (cultivar $\times$ year, $P<0.0005$, Table 3). In 1993 (year 5) and 1994 (year 6), Arrow out-yielded Apollo by 3.41 and $1.93 \mathrm{Mg} \mathrm{ha}^{-1}$, respectively (Table 4).

Harvesting fall regrowth (third cutting) decreased $(P=0.007)$ forage yield, compared with only cutting twice (Table 3 ). 
Averaged over years, grazing treatments, and cultivars, taking a third cutting reduced forage yield from 9.49 to $8.92 \mathrm{Mg}$ ha $^{-1}$ (data not shown). However, fall grazing did not affect forage yields $(P=0.83$, Table 3).

Over years, with Arrow, the percentage of alfalfa in the harvested forage $(80.6 \%)$ was greater $(P=0.0004)$ than that of Apollo $(58.5 \%)$ (data not shown). Cutting two versus three times did not affect alfalfa content of forage $(P=0.89)$, nor did fall grazing versus no grazing $(P=0.84)$ (Table 3$)$.

There were no differences between cultivars $(P=0.58)$ or harvest methods $(P=$ 0.34 ) for number of plants with visual symptoms of crown rot in 1994 (data not presented). When plants were removed and rated for crown rot in the fall of year 6 , there had been considerable reduction in plant density. Plant mortality averaged over harvest treatments was $88.7 \%$ for Apollo and $63.3 \%$ for Arrow. Crown rots for Apollo and Arrow were 28.6 and $29.5 \%$, respectively, and the average over harvest methods was $29.1 \%$. Overall, there was no evidence that grazing or a third cutting in the fall increased the incidence of crown rot in the plants remaining when the experiment was terminated.

Experiment 3. VW was first detected in both cultivars in year 2. Averaged over years and fungicide treatments, Apollo had higher $(P<0.0001)$ VW incidence (31.2\%) than Arrow (12.3\%) (Tables 3 and 5). Disease peaked in year 5 with Apollo and in year 6 with Arrow (data not shown). Incidence of VW in year 5 was $33.5 \%$ for Apollo and $10.5 \%$ for Arrow and in year 6 was $31.0 \%$ for Apollo and $13.5 \%$ for Arrow (data not shown). When averaged over cultivars and years, there was a $24.8 \%$ incidence of $\mathrm{VW}$ for the untreated check and $18.8 \%$ incidence for the fungicidetreated $(P=0.04$, Tables 3 and 6$)$.

Arrow maintained a denser $(P<0.0001)$ stand than Apollo, when averaged over fungicide treatments and years (55.1 versus $26.2 \%$, Tables 3 and 5). Plant density of both cultivars began to decline in year 4 and continued through year 6 (data not shown). Arrow had more plants remaining than Apollo in year 5, 74 versus $41 \%$, and in year 6, 50 versus $34 \%$ (data not shown). There was no effect of fungicide treatment on alfalfa plant density $(P=0.12$, Table 6$)$.

Forage yield, averaged over years and fungicide treatments, was greater for Arrow (8.94 $\mathrm{Mg} \mathrm{ha}^{-1}$ ) than for Apollo (8.17 $\left.\mathrm{Mg} \mathrm{ha}{ }^{-1}\right)(P<0.0001$, Table 5). Forage yields for Arrow and Apollo in years 4 and 5 were 10.38 and $9.32 \mathrm{Mg} \mathrm{ha}^{-1}$ and 6.63 and $6.03 \mathrm{Mg} \mathrm{ha}^{-1}$, respectively (data not shown). Forage yields of fungicide-treated and untreated plots, averaged over years and cultivars, did not differ $(P=0.07$, Table 6).

Arrow represented a greater $(P=0.02$, Table 3) proportion of harvested forage than did Apollo, when averaged over fun-

Table 4. Forage yields in $\mathrm{Mg} \mathrm{ha}^{-1}$ for cultivars over years 3 to 6 , with means averaged over two cutting and two grazing treatments, experiment $2^{\mathrm{a}, \mathrm{b}}$

\begin{tabular}{lcccc}
\hline Cultivar $^{\mathbf{c}}$ & $\mathbf{1 9 9 1}($ year 3) & $\mathbf{1 9 9 2}($ year 4) & $\mathbf{1 9 9 3}($ year 5) & $\mathbf{1 9 9 4}$ (year 6) \\
\hline Apollo (S) & 8.86 & 11.97 & 8.51 & 4.91 \\
Arrow (R) & 9.32 & 12.43 & 11.92 & 6.84 \\
\hline
\end{tabular}

a Plots were established 1 June 1989 (year 1), and treatments were initiated in 1990 (year 2).

${ }^{\mathrm{b}}$ Cultivar $\times$ year significant at $P<0.0005$, interaction LSD $0.05=1.72$.

${ }^{\mathrm{c}} \mathrm{S}$ and $\mathrm{R}$ are Verticillium wilt-susceptible and -resistant cultivars.

Table 5. Effect of cultivars, averaged over fungicide treatments and years, on Verticillium wilt (VW) incidence, forage yield, and alfalfa stand characteristics, experiment 3

\begin{tabular}{lcccc}
\hline & VW incidence & Forage yield & \multicolumn{2}{c}{ Alfalfa stand } \\
\cline { 4 - 5 } Cultivar $^{\mathbf{a}}$ & $(\boldsymbol{\%})$ & 8.17 & $\begin{array}{c}\text { Density } \\
(\boldsymbol{\%})\end{array}$ & $\begin{array}{c}\text { Alfalfa content } \\
(\boldsymbol{\%})\end{array}$ \\
\hline Apollo $(\mathrm{S})$ & 31.2 & 8.94 & 26.2 & 60.8 \\
Arrow $(\mathrm{R})$ & 12.3 & $<0.0001$ & 55.1 & 66.9 \\
$P>F^{\mathrm{b}}$ & $<0.0001$ & $<0.0001$ & 0.02 \\
\hline
\end{tabular}

${ }^{\mathrm{a}} \mathrm{S}$ and $\mathrm{R}$ are VW-susceptible and VW-resistant cultivars.

${ }^{\mathrm{b}}$ Probabilities are from Table 3.

Table 6. Fungicide effect, averaged over cultivars and years, on Verticillium wilt (VW) incidence, forage yield, and alfalfa stand characteristics, experiment 3

\begin{tabular}{lcccc}
\hline Fungicide & VW incidence & Forage yield & & \multicolumn{2}{c}{ Alfalfa stand } \\
\cline { 4 - 5 } treatment & $(\boldsymbol{\%})$ & 3.88 & $\begin{array}{c}\text { Density } \\
(\mathbf{\%})\end{array}$ & $\begin{array}{c}\text { Alfalfa content } \\
(\boldsymbol{\%})\end{array}$ \\
\hline Fungicide & 18.8 & 3.74 & 42.8 & 67.2 \\
No fungicide & 24.8 & 0.07 & 38.5 & 60.5 \\
$P>F^{\mathrm{b}}$ & 0.04 & 0.12 & 0.04 \\
\hline
\end{tabular}

${ }^{\text {a }}$ Benomyl was applied after each cutting from 1989 through 1993.

${ }^{\mathrm{b}}$ Probabilities are from Table 3.

gicide treatments and years (66.9 versus $60.8 \%$, Table 5). In the spring of year 5 , proportion of alfalfa in harvested forage was 85.1 and $78.8 \%$ for Arrow and Apollo (data not shown). Fungicide-treated plots had higher $(P=0.04)$ alfalfa content of harvested forage than untreated plots $(67.2$ versus $60.5 \%$, Table 6 ). Also, fungicidetreated plots had fewer $(P=0.05)$ broadleaf weeds in harvested forage than did untreated plots (11.9 and 17.1\%) (data not shown).

\section{DISCUSSION}

This is the first report on the effect of late season harvesting and fall grazing on plant density and forage yield in alfalfa in the presence of VW. Although experiment 1 was ended prematurely, both fall cutting and fall grazing of alfalfa after a killing frost reduced 2-cut forage yield the following year in the VW-moderately resistant cultivar Apollo II. Greatest yield occurred when fall growth was left uncut and ungrazed. Although not significantly different, plant density was also highest in the 2cut treatment. This confirms the earlier observation on the Padlock Ranch concerning the adverse effect of a late third cutting.

In experiments 2 and 3, both the VWsusceptible cultivar, Apollo, and the VWresistant cultivar, Arrow, increased in VW incidence through year 5. Over time, VW incidence increased in Apollo to a greater extent than in Arrow, and this was accompanied by a larger decline in alfalfa plant density. As a result, there was a significant forage yield advantage with Arrow.

Since infection of $V$. albo-atrum in the alfalfa plant occurs via freshly cut stems, it was hypothesized that a third cutting would increase disease incidence. However, results in experiment 2 , which included both 2-cut and 3-cut treatments, did not support this hypothesis. Although incidence of VW tended to be greater with two than with three cuts, the difference was not significant $(P=0.31)$. However, a third (fall) cutting did decrease plant stand and forage yield, while fall grazing did not. Late fall cutting most likely interfered with carbohydrate storage, thus decreasing winter survival (10).

Incidence of VW was much lower in experiment 3 than in experiment 2 in both cultivars. Incidences of $\mathrm{VW}$ in year 5 for Apollo and Arrow were 51 and 21\% (average of $36 \%$ ) for experiment 2 and 33.5 and $10.5 \%$ (average of $22 \%$ ) for experiment 3 , respectively. Plots in experiment 3 were only cut twice, while one-half of the plots in experiment 2 were cut three times, providing more sites for $V$. albo-atrum infection.

In contrast to fall cutting, fall grazing did not adversely affect alfalfa stands or yields. Fall grazing, in lieu of a third cutting, should extend the productivity of alfalfa stands one or more additional years, 
resulting in significant economic return (18). In addition, since hay drying conditions in the fall in Wyoming are generally poor, grazing would be a more practical method of utilizing fall forage.

VW-resistant cultivars were previously reported to out-perform susceptible cultivars in the presence of VW in Wyoming (5). In our present studies, the VWresistant cultivar Arrow had less VW, better plant stand, higher content of alfalfa in harvested forage, and out-yielded the susceptible cultivar Apollo in experiments 2 and 3. When experiment 2 was established in 1989, the highest level of resistance available in certified alfalfa cultivars was 31 to $50 \%$ resistant plants, classified as "Resistant." Currently, "Highly Resistant" (>50\% resistant plants) cultivars are available and should provide even better protection from VW.

Application of the systemic fungicide benomyl to the plant stubble following each harvest significantly $(P=0.04)$ reduced, but did not totally control, VW. However, it had only a limited effect on plant stand and yield in the resistant cultivar Arrow. Therefore, we were unable to determine if performance of Arrow was maximized in the presence of VW.

Incidence of crown rot of plants remaining in experiment 2 was similar for Apollo and Arrow. Biotic factors responsible for presence of crown rot were not determined, and no other diseases or insect pests were identified in the test site. It seems plausible that crown rot may have been responsible, at least in part, for the decline of plant stands. Although Arrow had $36.7 \%$ of its original $90 \%$ stand remaining at the end of the experiment, $29.5 \%$ of these plants had crown rot. Our results indicate that fall grazing imposed in our study did not increase crown rot. This is in agreement with studies conducted in Nevada (8). VW-resistant cultivars with increased resistance to crown rot could provide additional stand longevity and improved forage yield in alfalfa (17).

\section{ACKNOWLEDGMENTS}

We thank the Scott family, owners of the Padlock Ranch, and Ron Hossfeld, farm manager, for allowing and assisting us in this lengthy research project, and Roger Hybner, who assisted us in managing the experiments. We also thank David Craig, Melissa Gray, Bridgett Fishburn, Kathleen Brown, Roy Martens, Jean Williams, and others for assisting in the care of plots and in data collection, and Katherine Keeney for manuscript preparation. We also thank David Legg for advice on statistical analysis.

\section{LITERATURE CITED}

1. Christen, A. A. 1982. Demonstration of Verticillium albo-atrum within alfalfa seed. Phytopathology 72:412-414.

2. Christen, A. A. 1983. Incidence of external seedborne Verticillium albo-atrum in commercial seed lots of alfalfa. Plant Dis. 67:17-18.

3. Christen, A. A., and Peaden, R. N. 1981. Verticillium wilt in alfalfa. Plant Dis. 65:319-321.

4. Graham, J. H., Peaden, R. N., and Evans, D. W. 1977. Verticillium wilt of alfalfa found in the United States. Plant Dis. Rep. 61:337-340.

5. Gray, F. A., Page, M. S., Legg, D. E., and Hossfeld, R. L. 1992. Evaluating alfalfa for field resistance to Verticillium wilt. J. Prod. Agric. 5:273-278.

6. Gray, F. A., and Roth, D. A. 1982. Verticillium wilt of alfalfa in Wyoming. Plant Dis. 66:1080.

7. Isaac, I. 1957. Wilt of lucerne caused by species of Verticillium. Ann. Appl. Biol. 45:550558.

8. Jensen, E. H., Skivington, R. R., and Bohman, V. R. 1981. Dormant season grazing of alfalfa. Univ. NV, Reno (NV-Reno), Agric. Exp. Stn. Bull. R142.

9. Jimenez-Diaz, R. M., and Millar, R. L. 1986. Lack of systemic colonization of alfalfa plants after inoculation of uninjured leaves with conidia of Verticillium albo-atrum. Plant Dis. 70:509-515.
10. Kust, C. A., and Smith, D. 1961. Influence of harvest management on the level of carbohydrate reserves, longevity of stands, and yields of hay and protein from Vernal alfalfa. Crop Sci. 1:267-269.

11. Leath, K. T., and Pennypacker, B. W. 1990. Verticillium wilt. Pages 39-41 in: Compendium of Alfalfa Diseases. 2nd ed. D. L. Stuteville and D. C. Erwin, eds. American Phytopathological Society, St. Paul, MN.

12. Olsen, S. R., and Sommers, L. E. 1982. Phosphorus. Chapter 24 in: Agronomy Monograph \#9, Methods of Soil Analysis, Part 2, Chemical and Microbiological Properties. 2nd ed. American Society of Agronomy, Madison, WI.

13. Page, M. S., Gray, F. A., and Hossfeld, R. L. 1991. Infection status of healthy-appearing plants of resistant cultivars in Verticillium wiltinfected fields. Pages 24-26 in: Western Alfalfa Improve. Conf., 7th.

14. Page, M. S., Gray, F. A., Legg, D. E., and Kearl, W. G. 1992. Economic impact and management of Verticillium wilt on irrigated alfalfa hay production in Wyoming. Plant Dis. 76:504-508.

15. Peaden, R. N., and Christen, A. A. 1984. A guide for identification of Verticillium wilt in alfalfa. U.S. Dep. Agric., Agric. Res. Serv. Agric. Info. Bull. 456.

16. Pennypacker, B. W., and Leath, K. T. 1985. Anatomical response of a susceptible alfalfa clone infected with Verticillium albo-atrum. Phytopathology 76:522-527.

17. Salter, R., Viands, D. R., and Lowe, C. C. 1984. Effects of harvest frequency and soil fertility on development of crown rot of alfalfa and implications on a breeding program. Page 2 in: N. Am. Alfalfa Improve. Conf., 29th.

18. Sedman, J. N. 2003. Economic analysis of harvest practices for alfalfa with substantial infestation of Verticillium wilt. M.S. thesis. University of Wyoming, Laramie.

19. Soltanpour, P. N., and Schwab, A. P. 1977. A new soil test for simultaneous extraction of macro and micro-nutrients in alkaline soils. Comm. Soil Sci. Plant Anal. 8(3):195-207.

20. Viands, D. R., Lowe, C. C., Bergstrom, G. C., Vaughn, D. L., and Hansen, J. L. 1992. Association of level of resistance to Verticillium wilt with alfalfa forage yield and stand. J. Prod. Agric. 5:504-509. 